\author{
T.A. Shmygaleva, A.A. Konysbayeva \\ Al-Farabi Kazakh National University, Almaty, Kazakhstan \\ (E-mail: aigerimk1@gmail.com)
}

\title{
Development of an algorithm for calculating the concentration of radiation defects during ion irradiation
}

\begin{abstract}
The paper considers mathematical modeling of radiation defect formation processes in materials under ion irradiation. Algorithms for calculating cascade probability functions (CPF) taking into account energy, spectra of primary knocked out atoms (PKA) and the concentration of radiation defects during ion irradiation loss are presented. The defect concentration was calculated for various incident particles and targets of the periodic table. The regularities of the behavior of the concentration of defects depending on various physical parameters are revealed. The calculation algorithm is presented in the form of flowcharts. The work was performed as part of the cascade-probability method, the essence of which is to obtain and further use CPF. CPFs have the meaning of the probability that a particle generated at a certain depth h' will reach the detection depth $\mathrm{h}$ after the nth number of collisions.
\end{abstract}

Keywords: algorithm, calculation, probability, regularity, cascade probability function, concentration, radiation defects, ion, results area.

\section{Introduction}

In recent years, much attention has been paid to the problems of mathematical modeling of radiation-physical processes. The development of mathematical models, calculation algorithms, objects of research allows us to describe many phenomena [1]. We consider computer simulation of radiation defect formation processes in solids when they are irradiated with various charged particles, and computer simulation features of cascade probability functions and radiation defects for ions. The necessity for a such work is related to the problem of controlling the evolution of defects in a solid, in order to obtain, ultimately, materials with desired properties. For metals, irradiation with ions is an effective way to change properties such as metal strength, corrosion resistance, fatigue, deprecation, etc. Without research in this direction, solid state radiation physics would remain a fairly academic occupation that is not of interest for practical applications [1-11]. A lot of works have been devoted to the problems of the interaction of particles with matter and the generation of radiation defects upon irradiation of matter with ions [5-13]. Most of the work in this direction is carried out as part of the cascade-probability method [14-17].

During the interaction of charged particles with matter along the path of their movement, continuous energy losses occur. These losses lead to a strong dependence of both the energy spectra of the incident particles themselves and of the initially knocked out atoms on the penetration depth. The range of interaction for the formation of PKA substantially depends on energy, and therefore it became necessary to obtain physical and mathematical models that take into account the real dependence of various parameters of an elementary act on energy and depth. Previously, in most cases, in specific calculations, the simplest cascade probability function $(\mathrm{CPF})$ was mainly used, this is not always justified, since the interaction path depends on the energy. It is necessary to study the behavior of the obtained CPFs, taking into account the energy losses for ions, to prove the properties that they must possess both from a physical and mathematical point of view, develop calculation algorithms and calculate the CPF depending on the number of interactions and the penetration depth of the particles, the primary knocked out atoms and concentration of radiation defects [18-20]. 


\section{Experimental}

Calculation of radiation defect concentration at ionic irradiation is made by formula [21, 22]:

$$
\begin{aligned}
C_{k}\left(E_{0}, h\right) & =\int_{E_{c}}^{E_{2} \max } W\left(E_{0}, E_{2}, h\right) d E_{2}, \\
E_{2 \max } & =\frac{4 m_{1} c^{2} m_{2} c^{2}}{\left(m_{1} c^{2}+m_{2} c^{2}\right)^{2}} E_{1} ;
\end{aligned}
$$

$m_{2} c^{2}$ - rest energy of ion. $C_{k}\left(E_{0}, h\right)$ is determined taking into account of particle energy at depth $h$ is $E_{1}(h)$. As $E_{1}(h)=E_{0}-\Delta E(h)$, that power waste on ionization and agitation is assigned by $\Delta E$, found corresponding depths of monitoring $h$ from Bete-Blokh [1] formula or Komarov-Kumakhov table [22]. Spectrum of primary expelled atoms is determined by following ratio:

$$
W\left(E_{0}, E_{2}, h\right)=\sum_{n=n_{0}}^{n_{1}} \int_{h-k \lambda_{2}}^{h} \psi_{n}\left(h^{\prime}\right) \exp \left(-\frac{h-h^{\prime}}{\lambda_{2}}\right) \frac{w\left(E_{1}, E_{2}, h^{\prime}\right) d h^{\prime}}{\lambda_{1}\left(h^{\prime}\right) \lambda_{2}},
$$

where $n_{0}, n_{1}$ - initial and finite value of interactions number from domain of cascade-probability function. Cascade-probability function $\psi_{n}\left(h^{\prime}\right)$, incoming to expression (2) is given by form:

$$
\begin{aligned}
& \psi_{n}\left(h^{\prime}\right)=\frac{1}{n ! \lambda_{0}^{n}}\left(\frac{E_{0}}{E_{0}-k h^{\prime}}\right)^{\frac{1}{\lambda_{0} a k}} \exp \left(\frac{h^{\prime}}{\lambda_{0}}\right)\left(\frac{\ln \left(\frac{E_{0}}{E_{0}-k h^{\prime}}\right)}{a k}-h^{\prime}\right)^{n}, \\
& \lambda_{1}\left(h^{\prime}\right)=\frac{1}{\sigma_{0} n_{0}\left(\frac{1}{a\left(E_{0}-k h^{\prime}\right)}-1\right)} \cdot 10^{24}(\mathrm{~cm}), \quad \lambda_{2}=\frac{1}{\sigma_{2} n_{0}} \cdot 10^{24}(\mathrm{~cm}) .
\end{aligned}
$$

Section of $\sigma_{2}$ calculated by Rutherford formula, $z_{1}$ - atomic number of flying particle, $z_{2}$ - atomic number of target. Spectrum of primary expelled atom (PEA) in elementary act is calculated by formula:

$$
w\left(E_{1}, E_{2}\right)=\frac{d \sigma\left(E_{1}, E_{2}\right) / d E_{2}}{\sigma\left(E_{1}\right)} .
$$

Substituting the expression (4) in formulae (1) and (2), we found:

$$
C_{k}\left(E_{0}, h\right)=\frac{E_{d} E_{2 \max }}{E_{2 \max }-E_{d}} \int_{E_{c}}^{E_{2} \max } \frac{d E_{2}}{E_{2}^{2}} \sum_{n=n_{0}}^{n_{1}} \int_{h-k \lambda_{2}}^{h} \psi_{n}\left(h^{\prime}\right) \exp \left(-\frac{h-h^{\prime}}{\lambda_{2}}\right) \frac{d h^{\prime}}{\lambda_{1}\left(h^{\prime}\right) \lambda_{2}} .
$$

operating transformations, we get to following ratio:

$$
C_{k}\left(E_{0}, h\right)=\frac{E_{d}}{E_{c}} \frac{E_{2 \max }-E_{c}}{E_{2 \max }-E_{d}} \sum_{n=n_{0}}^{n_{1}} \int_{h-k \lambda_{2}}^{h} \psi_{n}\left(h^{\prime}\right) \exp \left(-\frac{h-h^{\prime}}{\lambda_{2}}\right) \frac{d h^{\prime}}{\lambda_{1}\left(h^{\prime}\right) \lambda_{2}},
$$

where $E_{d}$ - average energy of displacement, $E_{0}$ - initial energy of particle, $E_{c}$ - boundary energy, $E_{2 \max }$ - maximum energy, transmitting to atom at head-on collision, $\psi n\left(h^{\prime}\right)$ - cascade-probability function. 
Concentration of radiation defects is made by formula (1). It is impossible to put expression in the form of (3) instead of $\psi_{n}\left(h^{\prime}\right)$ as a repletion appears in every term of cascade-probability function (CPF). Expression for $\psi_{n}\left(h^{\prime}\right)$ used in the form [20]:

$$
\begin{gathered}
\Psi_{n}\left(h^{\prime}, h, E_{0}\right)= \\
=\exp \left(-\ln n !-n \ln \lambda_{0}-\frac{1}{\lambda_{0} a k} \ln \left(\frac{E_{0}}{E_{0}-k h^{\prime}}\right)+\frac{h^{\prime}}{\lambda_{0}}+n \ln \left(\frac{\ln \left(\frac{E_{0}}{E_{0}-k h^{\prime}}\right)}{a k}-h^{\prime}\right)\right) .
\end{gathered}
$$

2 Results and Discussion

Results of calculations are given in 1-2 figures. Algorithm of calculations is given in the form of logic diagram $(1,2)$. As the calculations show (Figure 1, 2), with an increase in the threshold energy, the curves pass much lower, the transition through the maximum is realized smoother. The concentration of radiation defects depending on the depth increases, reaching a maximum, then decreases to 0 .

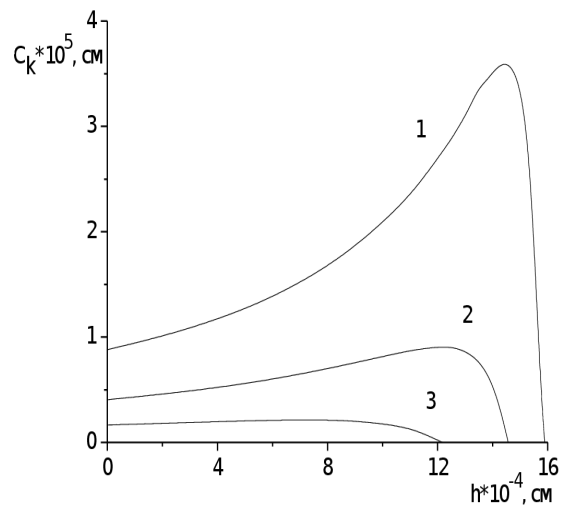

(a)

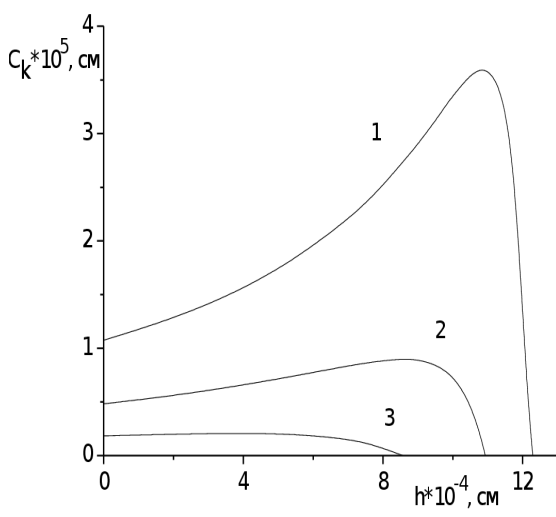

(b)

Figure 1. Dependence of the concentration of radiation defects on depth upon irradiation of silicon with silver ions at: (a) $E_{0}=1000 \mathrm{keV}, E_{c}=50 \mathrm{keV}$ (1), $100 \mathrm{keV}$ (2), $200 \mathrm{keV}$ (3);

(b) $E_{0}=800 \mathrm{keV}, E_{c}=50 \mathrm{keV}(1), 100 \mathrm{keV}(2), 200 \mathrm{keV}$ (3)

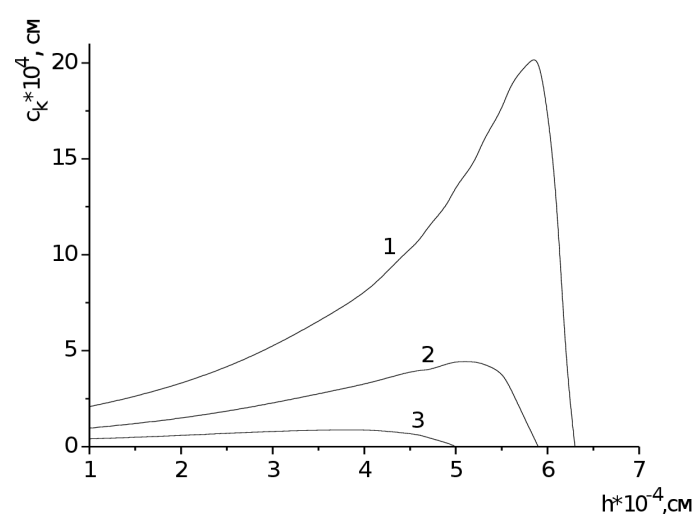

Figure 2. Dependence of the concentration of radiation defects on depth during ion irradiation for aluminum in iron at $E_{0}=1000 \mathrm{keV} ; E_{c}=50(1), 100(2), 200(3) \mathrm{keV}$

The finding of area of result of radiation defect concentration at ionic irradiation has allowed revealing the following regularities:

1. The interval of area of result displaces to the right with reduction of initial energy of primary particle, values of radiation defect concentration increase.

2. Calculating time strongly increases and reaches tens of hours (table 1,2) at the great atomic weight of a flying particle and small atomic weight of target. 
Algorithmic logic diagram of calculation of CK $\left(E_{0}, h\right)$ :

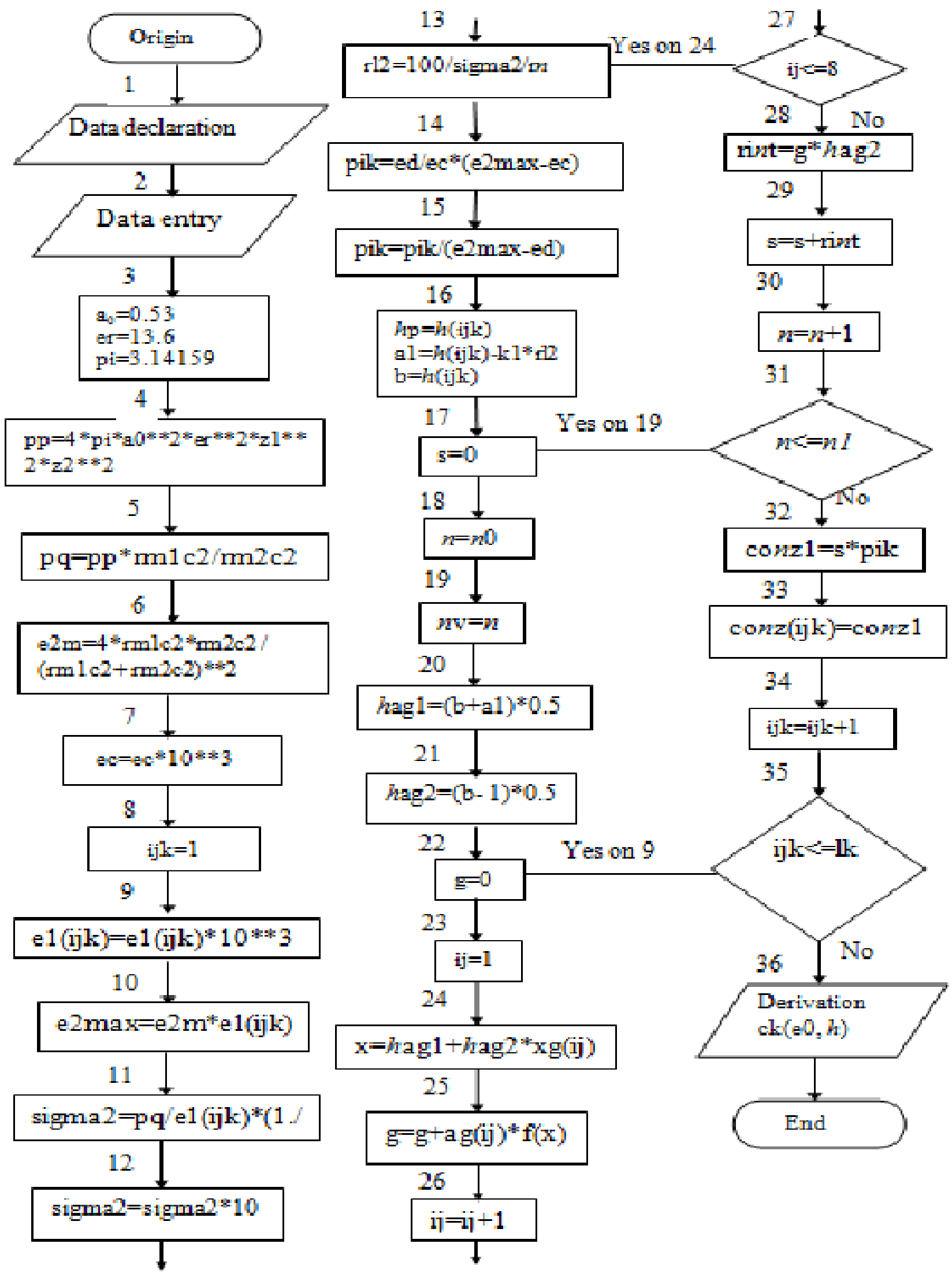


Logic diagram of calculation function $f\left(h_{1}\right)$ :

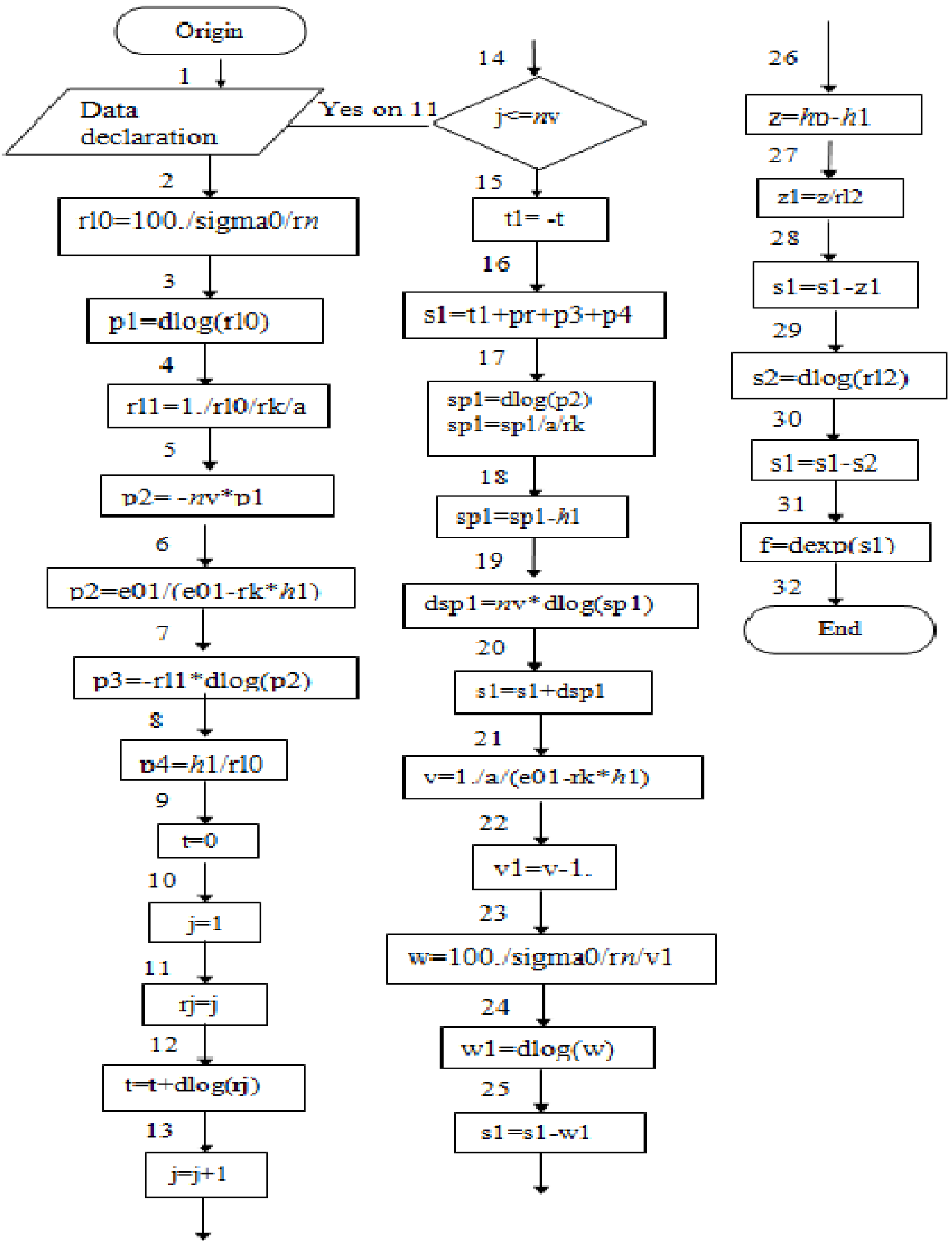


Definitional domain boundaries of radiation defect concentration, numbers of interactions and calculating time for germanium in aluminium at $E_{c}=50 \mathrm{keV}$ and $E_{0}=1000 \mathrm{keV}$

\begin{tabular}{|c|c|c|c|c|c|}
\hline$h \cdot 10^{4}, \mathrm{~cm}$ & $C_{k}, \mathrm{~cm}^{-1}$ & $E_{0}, \mathrm{keV}$ & $n_{0}$ & $n_{1}$ & $\tau$ \\
\hline 0,1 & 31453 & 1000 & 342 & 663 & $5^{\prime \prime} 80$ \\
\hline 2,0 & 34641 & 900 & 10319 & 11772 & $1^{\prime} 26^{\prime \prime}$ \\
\hline 4,0 & 38790 & 800 & 22509 & 24628 & $4^{\prime} 10^{\prime \prime}$ \\
\hline 6,0 & 44061 & 700 & 36526 & 39213 & $7^{\prime} 26^{\prime \prime}$ \\
\hline 8,1 & 51426 & 600 & 53795 & 57102 & $12^{\prime} 57^{\prime \prime}$ \\
\hline 10,1 & 61078 & 500 & 73611 & 77333 & $19^{\prime} 31^{\prime \prime}$ \\
\hline 12,0 & 74085 & 400 & 96941 & 101215 & $29^{\prime} 03^{\prime \prime}$ \\
\hline 13,0 & 83450 & 350 & 111802 & 116424 & $36^{\prime} 54^{\prime \prime}$ \\
\hline 14,0 & 95401 & 300 & 129231 & 134213 & $44^{\prime} 35^{\prime \prime}$ \\
\hline 14,3 & 99134 & 280 & 135104 & 140152 & $47^{\prime} 20^{\prime \prime}$ \\
\hline 14,7 & 105238 & 260 & 143505 & 148774 & $53^{\prime} 36^{\prime \prime}$ \\
\hline 15,1 & 112049 & 240 & 152665 & 158192 & $59^{\prime}$ \\
\hline 15,5 & 119653 & 220 & 162734 & 168361 & $1^{\circ} 03^{\prime}$ \\
\hline 15,8 & 124508 & 200 & 171000 & 176816 & $1^{\circ} 09^{\prime}$ \\
\hline 16,2 & 133078 & 180 & 183184 & 189101 & $1^{\circ} 14^{\prime}$ \\
\hline 16,6 & 142065 & 160 & 197029 & 203203 & $1^{\circ} 23^{\prime}$ \\
\hline 16,9 & 144496 & 140 & 208809 & 215170 & $1^{\circ} 30^{\prime}$ \\
\hline 17,3 & 148840 & 120 & 226991 & 233671 & $1^{\circ} 44^{\prime}$ \\
\hline 17,6 & 135244 & 100 & 243135 & 250085 & $1^{\circ} 55^{\prime}$ \\
\hline 18,0 & 99266 & 80 & 269617 & 277085 & $2^{\circ} 17^{\prime}$ \\
\hline 18,1 & 48552 & 70 & 277471 & 284876 & $2^{\circ} 22^{\prime}$ \\
\hline 18,3 & 0 & 60 & 295266 & 302961 & $2^{\circ} 33^{\prime}$ \\
\hline
\end{tabular}

Definitional domain boundaries of radiation defect concentration, numbers of interactions and calculating time

for silver in silicon at $E_{c}=200 \mathrm{keV}$ and $E_{0}=1000 \mathrm{keV}$

\begin{tabular}{|c|c|c|c|c|c|}
\hline$h \cdot 10^{5}, \mathrm{~cm}$ & $C_{k}, \mathrm{~cm}^{-1}$ & $E_{0}, \mathrm{keV}$ & $n_{0}$ & $n_{1}$ & $\tau$ \\
\hline 0,01 & 16563 & 1000 & 174 & 417 & $4^{\prime \prime} 35$ \\
\hline 1,81 & 17930 & 900 & 60299 & 63742 & $4^{\prime \prime} 38$ \\
\hline 3,60 & 19347 & 800 & 130090 & 135256 & $15^{\prime}$ \\
\hline 5,37 & 20642 & 700 & 210534 & 217106 & $46^{\prime}$ \\
\hline 7,11 & 21479 & 600 & 304159 & 311851 & $1^{\circ} 33^{\prime}$ \\
\hline 8,84 & 20904 & 500 & 416958 & 426047 & $2^{\circ} 36^{\prime}$ \\
\hline 10,52 & 16167 & 400 & 553995 & 564515 & $4^{\circ} 11^{\prime}$ \\
\hline 11,35 & 10063 & 350 & 636131 & 647055 & $7^{\circ} 39^{\prime}$ \\
\hline 12,17 & 0 & 300 & 730486 & 742372 & $9^{\circ} 33^{\prime}$ \\
\hline
\end{tabular}

3. The interval of area of result greatly displaces to the right and increases with increase of atomic number of a flying particle, value of concentration in a point of maximum and values of concentration strongly increase. With an increase in the atomic number of the target for the same incident particle, 
the value of the function at the maximum point increases slightly, the depths decrease, i.e. more vacancy clusters are formed in the heavier target, especially in the near-surface region.

4. Initial and final values of number of interactions increase depending on penetration depth, the interval of area of result $\left(n_{0}, n_{i}\right)$ also increases and displaces to the right.

5. Values of concentration abruptly increase and calculating time increases at the great atomic weight of a flying particle and target, for the rest a behavior of area of result similar increases.

6. If the atomic weight of the incident particle is much less than the atomic number of the target, then the concentration of radiation defects becomes zero at energies significantly higher than the threshold energy. As a rule, the conversion to zero occurs at $E_{1}=50,60 \mathrm{keV}$ for a concentration calculated at $E_{c}=50 \mathrm{keV}$.

7. When increasing threshold energy at the same penetration depth, the values of the concentration of radiation defects decrease significantly, the boundaries of the result area do not change.

\section{Conclusion}

Thus, the work developed algorithms for calculating the CPF, PKA spectra, and the concentration of radiation defects. Calculations were made for silver in silicon, germanium in aluminum, aluminum in iron at various values of the initial and threshold energy. Regularities of the behavior and finding of the region of the result of the concentration of radiation defects are obtained depending on the initial ion energy, threshold energy, penetration depth, atomic number of the incident particle and target. It should be noted that earlier in the calculations, energy losses were not taken into account and the simplest CVF was used. In this work, we used the expressions for the CPF, PKA spectra, and defect concentrations taking into account energy losses. The obtained models and calculation algorithms can be used by specialists in the field of solid state radiation physics. Using the results obtained, they can be used for calculations of various incident particles and targets of the periodic table.

\section{References}

1 Boos, E.G., Kupchishin, A.A., Kupchishin, A.I., Shmygalev, E.V. \& Shmygaleva, T.A. (2015). Cascade and probabilistic method, solution of radiation and physical tasks, Boltzmann's equations. Communication with Markov's chains. Almaty: KazNPU after Abay, Scientific Research Institute for New Chemical Technologies and Materials under al-Farabi KazNU.

2 Czarnacka, K., Komarov, F.F., Romanov, I.A., Zukowski, P. \& Parkhomenko, I.N. (2017). C measurements and dielectric properties of nitrogen-rich silicon nitride thin films. Proceedings of the 2017 IEEE 7th International Conference on Nanomaterials: Applications and Properties, 5, 86, 657-669 [in Russian].

3 Komarov, F.F., Milchanin, O.V., Parfimovich, I.D., Tkachev, A.G. \& Bychanok, D.S. (2017). Absorption and Reflectance Spectra of Microwave Radiation by an Epoxy Resin Composite with Multi-Walled Carbon Nanotubes. Journal of Applied Spectroscopy, 84, 4, 570-577.

4 Komarov, F.F. (2017). Nano- and microstructuring of solids by swift heavy ions. Physics-Uspekhi, $187,5,465-504$.

5 Komarov, F.F., Romanov, I.A., Vlasukova, L.A., Mudryi, A.V. \& Wendler, E. (2017). Optical and Structural Properties of Silicon with Ion-Beam Synthesized InSb Nanocrystals. Spectroscopy, 120, 1, 204-207.

6 Komarov, F.F., Konstantinov, S.V., Strel'nitskij, V.E.\& Pilko, V.V. (2016). Effect of Helium ion irradiation on the structure, the phase stability, and the microhardness of TiN, TiAlN, and TiAlYN nanostructured coatings. Technical Physics, 61, 5, 696-702.

7 Al'zhanova, A., Dauletbekova, A., Komarov, F., Akilbekov, A. \& Zdorovets, M. (2016). Peculiarities of latent track etching in $\mathrm{SiO} 2 / \mathrm{Si}$ structures irradiated with $\mathrm{Ar}, \mathrm{Kr}$ and Xe ions. Nuclear 
Instruments and Methods in Physics Research, Section B: Beam Interactions with Materials and Atoms, 374, 1, 121-124.

8 Komarov, F.F., Zayats, G.M., Komarov, A.F.,Michailov, V.V. \& Komsta, H. (2015). Simulation of radiation effects in SiO2/Si Structures. Acta Physica Polonica A, 3, 1, 854-860.

9 Komarov, F., Uglov, V., Vlasukova, L., Zlotski, S.\& Yuvchenko, V. (2015). Drastic structure changes in pre-damaged GaAs crystals irradiated with swift heavy ions. Nuclear Instruments and Methods in Physics Research, Section B: Beam Interactions with Materials and Atoms, 360, 4, 150-155.

10 Kodanova, S.K., Ramazanov, T.S., Issanova, M.K., Golyatina, R.I. \& Maiorov, S.A. (2018). Calculation of ion stopping in dense plasma by the Monte-Carlo method. Journal of Physics: Conference Series, 946, 1, 148-154.

11 Smyrnova, K.V., Pogrebnjak, A.D., Beresnev, V.M., Kravchenko, Y.O.\& Bondar, O.V. (2018). Microstructure and Physical-Mechanical Properties of (TiAlSiY)N Nanostructured Coatings Under Different Energy Conditions. Metals and Materials International, 24, 2, 241-439.

12 Kozhamkulov, B.A., Kupchishin, A.I., Bitibaeva, Z.M.\& Tamuzs, V.P. (2017). Radiation-Induced Defect Formation in Composite Materials and Their Destruction Under Electron Irradiation. Mechanics of Composite Materials, 53, 1, 59-64.

13 Kupchishin, A.I. (2017). On positrons irradiation in the defects of vacancy type. IOP Conference Series: Materials Science and Engineering, 184, 1, 234-248.

14 Kupchishin, A.I., Niyazov, M.N., Voronova, N.A., Kirdiashkin, V.I.\& Abdukhairova, A.T. (2017). The effect of temperature, static load and electron beam irradiation on the deformation of linear polymers. IOP Conference Series: Materials Science and Engineering, 168, 1, 229-274.

15 Kupchishin, A.I., Kupchishin, A.A.\& Voronova, N.A. (2016). Cascade-probabilistic methods and solution of Boltzman type of equations for particle flow. IOP Conference Series: Materials Science and Engineering, 110, 1, 123-129.

16 Kupchishin, A.I., Kupchishin, A.A., Voronova, N.A.\& Kirdyashkin, V.I. (2016). Positron sensing of distribution of defects in depth materials. IOP Conference Series: Materials Science and Engineering, 110, 4, 248-258.

17 Kupchishin, A.I., Shmygalev, E.V., Shmygaleva, T.A.\& Jorabayev, A.B. (2015). Relationship between markov chains and radiation defect formation processes by ion irradiation. Modern Applied Science, 9, 3, 59-70.

18 Kupchishin, A.I., Kupchishin, A.A., Shmygalev, E.V., Shmygaleva, T.A.\& Tlebaev, K.B. (2014). Calculation of the spatial distribution of defects and cascade- Probability functions in the materials. Journal of Physics: Conference Series, 552, 2, 89-96.

19 Voronova, N. A., Kupchishin, A.I., Kupchishin, A.A., Kuatbayeva, A.A.\& Shmygaleva, T.A.(2018). Effect of the nanoparticles with various structures and morphologies on the thermo-mechanical properties of epoxy-based carbon fiber-reinforced plastics, "Computer Modeling of Depth Distribution of Vacancy Nanoclusters in Ion-Irradiated Materials". Key Engineering Materials, 769, 358-363.

20 Kupchishin, A., Voronova, N., Shmygaleva, T.\& Kupchishin, A.(2018). Computer Simulation of Vacancy Clusters Distribution by Depth in Molybdenum Irradiated by Alpha Particles. Key Engineering Materials, 781, 3-72.

21 Kupchishin, A.I., Kupchishin, A.A., Shmygaleva, T.A.\& Shafii, C.A. (2019). Computer simulation of the energy spectra of PKA in materials irradiated by protons in the framework of the CascadeProbabilistic method. IOP Conference Series: Materials Science and Engineering, 510, 012024, 1-6.

22 Komarov F.F.\& Kumakhov M.A. (1980). Tables of spatial distribution parameters of ion-implanted impurities. BGU named after Lenin V.I. publisher, Minsk, 352. 
Т.А. Шмыгалева, А.А. Қонысбаева

\title{
Иондық сәулелеудегі радиациялық ақаулардың концентрациясын есептеу алгоритмдерін құрастыру
}

\begin{abstract}
Жұмыс каскадты-ықтималды әдіс аясында жасалынған, оның мәнісі - әртүрлі бөлшектерге арналған каскадты-ықтималды функциясын (КЫФ) алу және әрі қарай қолдануында болады. КЫФ ықтималдығының мәні - бірсыпыра "h" тереңдікте туындалған бөлшек "n" рет соқтығысуынан кейін белгілі бір "h" тереңдігіне жетуде. Мақалада есептеу сапасы мен уақытты қысқарту мақсатында әрекеттестіктер және бөлшектердің ену санына, иондық сәулелендіру кезіндегі радиациялық ақау концентрациясына байланысты каскадты-ықтималды функциясын (КЫФ) есептеуге арналған алгоритмдерді оңтайландыру ұсынылған. КЫФ және радиациялық ақаулар шоғырлануын есептеу үшін нәтиже аймағы, осы аймақ шекаралары мен есептеу қадамы табылады. Шекараларды іріктеу және есептеу қадамын автоматтандырылуы орындалған.
\end{abstract}

Kiлm сөздер: алгоритм, есептеу, ықтималдық, ұдайы, каскадты-ықтималды функциясы, концентрация, радиациялық ақаулар, ион, нәтиже аймағы.

\section{Т.А. Шмыгалева, А.А. Конысбаева}

\section{Разработка алгоритмов расчета концентрации радиационных дефектов при ионном облучении}

Работа выполнена в рамках каскадно-вероятностного метода, суть которого заключается в получении и дальнейшем использовании каскадно-вероятностных функций (КВФ) для различных частиц. КВФ имеют смысл вероятности того, что частица, сгенерированная на некоторой глубине $\mathrm{h}$, достигнет определенной глубины h после $n$-го числа соударений. Авторами предложена оптимизация алгоритмов для расчета каскадно-вероятностных функций (KВФ) в зависимости от числа взаимодействий и глубины проникновения частиц, концентрации радиационных дефектов при ионном облучении с целью уменьшения времени и качества расчета. Для расчета КВФ и концентрации радиационных дефектов находится область результата, границы этой области и шаг для расчета. Выполнена автоматизация подбора границ и шага для расчета.

Ключевые слова: алгоритм, расчет, вероятность, регулярность, каскадная функция вероятности, концентрация, радиационные дефекты, ион, область результатов. 